\title{
Morphological Characterization of the Renal Arteries in the Pig. Comparative Analysis with the Human
}

\author{
Caracterización Morfológica de las Arterias Renales \\ en el Cerdo. Análisis Comparativo con el Humano
}

Gómez Fabian Alejandro; Ballesteros Luis Ernesto \& Estupiñan Hernando Yesid

GÓMEZ, F. A.; BALLESTEROS, L. E. \& ESTUPIÑAN, H. Y. Morphological characterization of the renal arteries in the pig. Comparative analysis with the human. Int. J. Morphol., 35(1):319-324, 2017.

SUMMARY: In spite of its importance as an experimental model, information on the renal artery in pigs is scarce. The objective of this work was to determine the morphological characteristics of the renal artery (RA) and its branches in pigs. One hundred and twenty one (121) pairs of kidneys of pigs destined to slaughter by stunning were studied. The RA and its branches were perfused with polyester resin (Palatal $85 \%$ t Styrene $15 \%$ ) and subjected to KOH infusion (potassium hydroxide) for total corrosion. Calibers were measured, and trajectories and relations with adjacent arterial structures were evaluated. Continuous variables were assessed with Student's t test, and discrete variables with Pearson's chi square test. The significance level used was $\mathrm{p}<0.05$. The origin of the RA was symmetric in 57 specimens $(50.4 \%$ ), with the right renal artery being more cranial in $55 \%$ of the cases. Single renal arteries were seen in $98.4 \%$, without significant side differences ( $\mathrm{p}=0.31$ ). The caliber and length of the RA were $5.11 \mathrm{~mm}$ (SD 1.35) and 30.1 mm (SD 8.63), respectively. A pattern of RA expression that causes one cranial and one caudal polar branch (Type I) was observed in $97.1 \%$ of the cases. The distribution of the RA in cranial and caudal polar branches was found to be higher than what is described in the literature, since these morphometric features have not been reported in prior studies. These findings contribute to a better knowledge in the field of the compared anatomy of the kidney, and allow for applying the pig model in procedural and hemodynamic applications.

KEY WORDS: Renal artery; Polar branches; Pig; Segmental branches.

\section{INTRODUCCIÓN}

Previous studies indicate few morphological differences between the urinary systems of humans and pigs. The information available about the renal arterial irrigation is scarce, and has been obtained from a small number of specimens with a few superficial descriptions, thus resulting in unreliable findings and statistical analysis. (Hodson, 1986; Xu et al., 1994; Evan et al., 1996).

The renal arteries (RA) exhibit two basic patterns that are well described in the human and in a general manner in the pig (Graves, 1954; Evan et al.; Saldarriaga et al., $2008 \mathrm{a}, \mathrm{b})$. The pattern characterized by the presence of an artery that bifurcates near the hilum in cranial and caudal polar branches (pattern I) is the most common, even more so in the right kidney, whreas it is seen in both kidneys in 55 $\%$ of the cases. In pattern II, reported with greater frequency in the left kidney, the cranial polar branch is replaced by anterior and posterior segmental branches with one branch that irrigates the cranial pole emerging from the cranial polar branch (Evan et al.).
The presence of multiple RAs has not been reported in pigs (Evan et al.), in contrast with what has been fully described in humans, in a range of between 10-50\%, and appearing on both right and left sides. (Saldarriaga et al., 2008a,b; Shashikala et al., 2012; Aristotle et al., 2013; Saritha et al., 2013; Vatsala et al., 2014).

Morphometric studies of the RAs in pigs have not been reported despite its importance for the implementation of experimental and hemodynamic procedures using the vascular components of the urinary system of the pig (Kaouk et al., 2003; Hammond et al., 2004; Bagetti Filho et al., 2008). In addition, the characterization of the RA and its branches in pigs enriches the teaching-learning processes of compared anatomy with this species. This work seeks to generate meaningful information on this arterial structure through the evaluation of a specimen of commercial pigs that allow for involving this vascular structure within a context of comparative anatomy between human and pig kidneys. 


\section{MATERIAL AND METHOD}

This descriptive cross-sectional study evaluated the renal irrigation and their branches in 121 pairs of kidneys pigs of commercial breeds (crossings of Pietrain, Belgian Landrace, and Large White breeds) intended for slaughter with a mean age of 5 months and a weight of $85-90 \mathrm{~kg}$, obtained from Vijagual Refrigerating Plant of Bucaramanga - Colombia. The organs were subjected to an exsanguination process in a water source for 6 hours.

The vascular system was dissected upon application of a visual repair with 2.0 silk at the anterior end of the abdominal aorta. The posterior ends of that vessel and of its collateral vessels going to organs other than the kidneys were ligated; then, a 14 catheter was passed through the aorta, used to infuse semisynthetic polyester resin, consisting of a mixture of $85 \%$ Palatal GP40L with $15 \%$ styrene, and dyed red. Subsequently, the anatomical pieces were subjected to corrosion by immersion in a $15 \%$ potassium hydroxide $(\mathrm{KOH})$ solution of for ten days, a procedure that permitted to observe the details of the arterial structures and their collateral branches from their origin to their distal segments; the outer diameters of the RAs and their main collateral branches were measured at $0.5 \mathrm{~cm}$ of its origins with a digital calibrator (Mitutoyo ${ }^{\circledR}$ ). Similarly, length, width and thickness were measured for each of the kidneys evaluated.

The morphologic expression of the RA was typified according to Evan et al. criteria; with a Ia pattern, where the RA divides into two polar branches, cranial (CrPB) and caudal (CaPB). The polar branches are in turn divided into anterior (ASB) and posterior (PSB) segmental branches, which irrigate the anterior and posterior portions of the cranial and caudal poles of the kidney, with three to four inter-lobar branches emerging from them. In contrast, in pattern $\mathrm{Ib}$ the $\mathrm{CrPB}$ is usually very short, having a few millimeters in length or even being altogether absent, with both ASB and PSB emerging directly from the renal artery. There is however a $\mathrm{CaPB}$ in pattern Ib whose distribution is almost identical to that described for the $\mathrm{CaPB}$ of pattern Ia.

In pattern II, only one CaPB emerges from the RA, from which a branch originates that goes to the cranial pole of the kidney; additionally, there is no CrPB for the cranial pole, and the two segmental branches originate directly from the RA (Evan et al.). For this study we have added a Ic pattern, where the presence of two polar branches combines with an intermediate branch (IB) between the two vessels described above. Furthermore, pattern III was considered, with presence of multiple renal arteries.
The data obtained were recorded in an Excel table. Photographic records were obtained from each of the specimens evaluated. The continuous variables were analyzed with Student's t test, whereas discrete variables were assessed using the Chi square test. The results were evaluated with the "Epi-Info 3.5.4" statistical program, with a level of significance of $p<0.05$.

\section{RESULTS}

We evaluated 121 pairs of kidneys of pigs with a mean length of $120 \mathrm{~mm}$ (SD 9.22) and a mean thickness of 27.9 mm (SD 4.48) (Table I).

The origin of the RA was symmetric in 57 specimens $(50.4 \%)$ and asymmetric in 56 specimens $(49.6 \%)$, with the right artery being more cranial in $55 \%$ of the cases. The distance between the origins of the left and right RAs was $4.48 \mathrm{~mm}$ (SD 4.79) (Fig. 1A). A single right RA was observed in 120 specimens $(99.2 \%)$ and a double RA was seen in 1 case $(0.8 \%)$; whereas in the left kidney a single RA was found in 118 kidneys ( $97.5 \%$ ) and a double RA in 3 cases (2.5\%), without significant differences with respect to the side ( $\mathrm{p}=0.31$ ). The caliber of the RA was $5.11 \mathrm{~mm}$ (SD 1.35) (4.92 $\mathrm{mm}$ for the right side and $5.29 \mathrm{~mm}$ for the left). The right RA was $33.78 \mathrm{~mm}$ in length (SD 9.31), whereas the left RA was $26.33 \mathrm{~mm}$ (SD 7.95), without significant differences $(\mathrm{p}=0.51)$ (Fig. 1B).

The right RA exhibited a Type I distribution pattern in 118 specimens $(97.5 \%)$, Type II in 2 cases (1.7 $\%$ ) (Fig. 1C) and Type III in one kidney (0.8\%) (Fig. 1B). The 118 Type I specimens exhibited the following distribution: Type Ia, 78 cases (66.1\%) (Fig. 1D), Type Ib, 28 cases (23.7 $\%$ ) (Fig. 1E), and Type Ic, 12 specimens (10.2\%) (Fig. 1F).

Type I distribution pattern was predominant in the left RA with 117 specimens (96.7\%), whereas Type II was observed in one case $(0.8 \%)$ and Type III in 3 cases $(2.5$ $\%)$ (Fig. 1B). Type I distribution pattern for the left kidney was as follows: Type Ia, 81 cases (69.2\%) (Fig. 1D), Type Ib, 29 cases $(28.8 \%)$, and Ic Type, 7 specimens $(2 \%)$.

In the right kidney, the $\mathrm{CrPB}$ of the RA was present in 101 specimens (83.5\%), whereas the $\mathrm{CaPB}$ was observed in 119 cases $(98.3 \%)$ (Fig. 1D). The IB had a caliber of 2.44 mm (SD 0.67) (Table II).

The CrPB was observed in 107 left kidney specimens ( 88.4 $\%$ ), whereas the $\mathrm{CaPB}$ was present in $100 \%$ of these cases (Fig. 1D). The caliber of the IB was $1.78 \mathrm{~mm}$ (SD 0.47) (Table III). 
Table I. External morphometric measurements of 121 pairs of pig kidneys. Expressed in millimeters with standard deviations.

\begin{tabular}{lccccc}
\hline & Kidney length (SD) & Cranial pole width & Hilum width (SD) & Caudal pole width & Thickness (SD) \\
\hline Right Kidney & $119.9(0948)$ & $56.6(6.26)$ & $52.4(5.59)$ & $52.6(6.93)$ & $28(4.25)$ \\
Left Kidney & $121.5(8.96)$ & $57.2(7.2)$ & $52.8(6.64)$ & $52.1(6.53)$ & $27.82(4.7)$ \\
TOTAL & $120(9.22)$ & $56.9(6.73)$ & $52.6(6.12)$ & $52.4(6.73)$ & $27.9(4.48)$ \\
\hline
\end{tabular}

SD: standard deviation
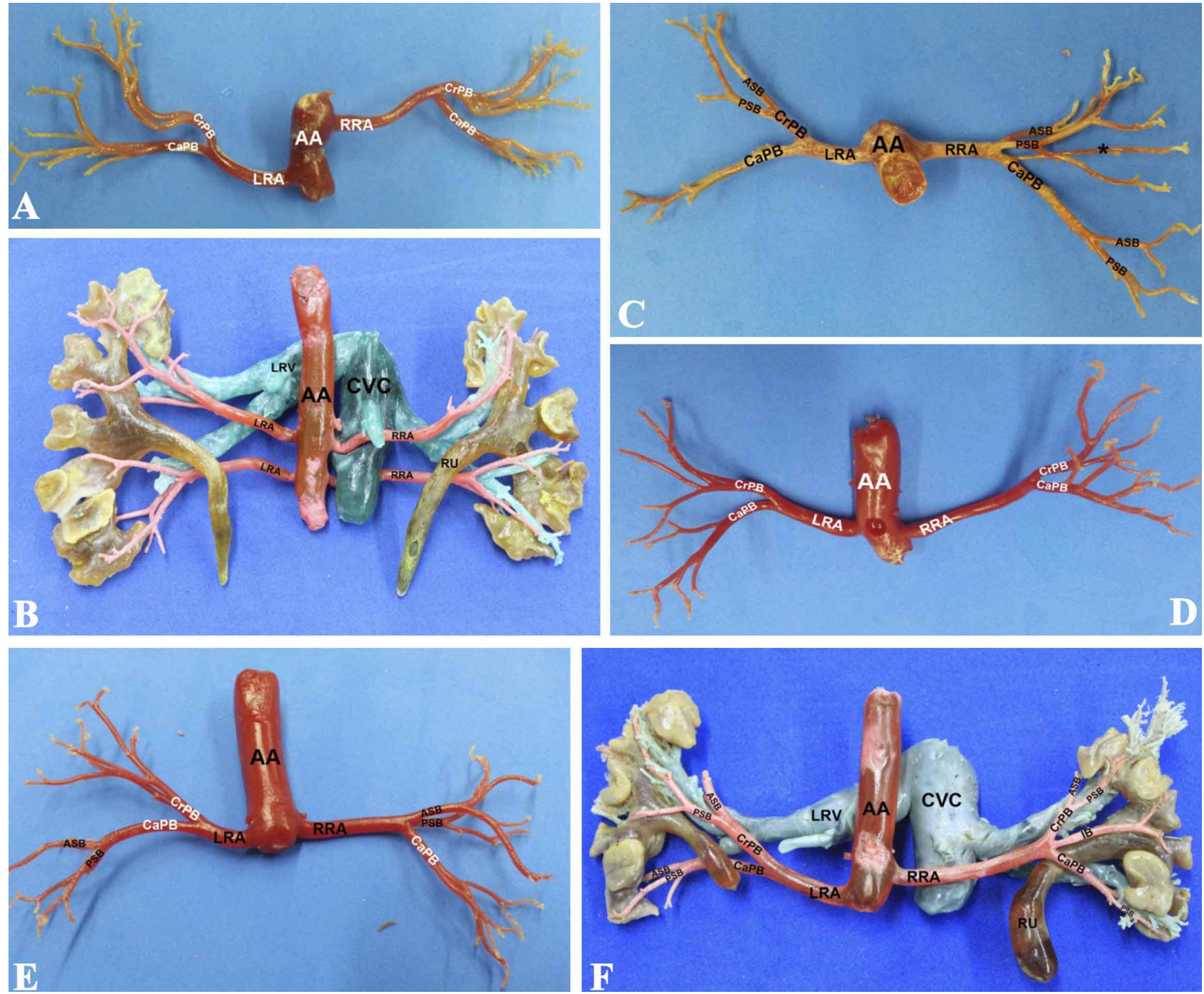

Fig. 1. A. Asymmetric origin of the renal arteries. AA: abdominal aorta; RRA: right renal artery; LRA: left renal artery: CrPB: cranial polar branch; CaPB: caudal polar branch. B. Double bilateral renal artery. For its segmental distribution pattern corresponds to Type III. AA: abdominal aorta; CVC: caudal vein cava; RRA: right renal artery; LRA: left renal artery; LRV: left renal vein; RU: right ureter. C. Type II distribution pattern, right side; Type Ia, left side. AA: abdominal aorta; RRA: right renal artery; LRA: left renal artery: CrPB: cranial polar branch; CaPB: caudal polar branch; ASB: anterior segmental branch; PSB:posterior segmental branch; *: branch originated from the CaPB to irrigate the cranial pole. D. Type Ia distribution pattern bilateral. AA: abdominal aorta; RRA: right renal artery; LRA: left renal artery: $\mathrm{CrPB}$ : cranial polar branch; CaPB: caudal polar branch. E. Type Ib distribution pattern, right side; Type Ia, left side. AA: abdominal aorta; RRA: right renal artery; LRA: left renal artery: CrPB: cranial polar branch; CaPB: caudal polar branch; ASB: anterior segmental branch; PSB: posterior segmental branch. F. Type Ic distribution pattern, right side; Type Ia, left side. AA: abdominal aorta; CVC: caudal vein cava; RRA: right renal artery; LRA: left renal artery; LRV: left renal vein; RU: right ureter. CrPB: cranial polar branch; CaPB: caudal polar branch; IB: intermediate branch; ASB: anterior segmental branch; PSB: posterior segmental branch. 
GÓMEZ, F. A.; BALLESTEROS, L. E. \& ESTUPIÑAN, H. Y. Morphological characterization of the renal arteries in the pig. Comparative analysis with the human. Int. J. Morphol., 35(1):319-324, 2017.

Table II. Frequency and morphometry of the polar and intermediate branches of the right renal artery. Expressed in millimeters with standard deviations.

\begin{tabular}{lllllllll}
\hline & Caliber (SD) & Length (SD) & $\begin{array}{l}\text { ASB } \\
\text { caliber } \\
\text { (SD) }\end{array}$ & $\begin{array}{l}\text { ASB length } \\
\text { (SD) }\end{array}$ & $\begin{array}{l}\text { No. of inter- } \\
\text { lobar } \\
\text { branches (SD) }\end{array}$ & $\begin{array}{l}\text { PSB } \\
\text { caliber (SD) }\end{array}$ & $\begin{array}{l}\text { PSB } \\
\text { length (SD) }\end{array}$ & $\begin{array}{l}\text { No. of inter- } \\
\text { lobar } \\
\text { branches (SD) }\end{array}$ \\
\hline $\mathrm{CrPB}$ & $3.38(0.75)$ & $14.92(8.09)$ & $2.39(0.6)$ & $2105(10.1)$ & $3.01(1.05)$ & $2.3(1.1)$ & $22.58(9)$ & $3.1(1.17)$ \\
$\mathrm{CaPB}$ & $3.23(0.77)$ & $19.99(0839)$ & $2.09(0.6)$ & $17.02(8.98)$ & $2.88(1.14)$ & $2.3(0.8)$ & $17.51(7.3)$ & $3.21(1.12)$ \\
$\mathrm{IB}$ & $2.44(0.67)$ & $9.52(10.65)$ & & & & & &
\end{tabular}

CrPB: Cranial polar branch. CaPB: Caudal polar branch. IB: Intermediate branch. ASB: Anterior segmental branch. PSB: Posterior segmental branch. SD: Standard deviation

Table III. Frequency and morphometry of the polar and intermediate branches of the left renal artery. Expressed in millimeters with standard deviations.

\begin{tabular}{lllllllll}
\hline & $\begin{array}{l}\text { Caliber } \\
\text { (SD) }\end{array}$ & Length (SD) & $\begin{array}{l}\text { ASB } \\
\text { caliber } \\
\text { (SD) }\end{array}$ & $\begin{array}{l}\text { ASB length } \\
\text { (SD) }\end{array}$ & $\begin{array}{l}\text { No. of inter- } \\
\text { lobar } \\
\text { branches (SD) }\end{array}$ & $\begin{array}{l}\text { PSB } \\
\text { caliber (SD) }\end{array}$ & $\begin{array}{l}\text { PSB } \\
\text { length (SD) }\end{array}$ & $\begin{array}{l}\text { No. of inter- } \\
\text { lobar } \\
\text { branches (SD) }\end{array}$ \\
\hline CrPB & $3.31(0.71)$ & $16.31(0828)$ & $2.34(0.6)$ & $20.84(10.6)$ & $3.04(1.2)$ & $2.27(0.6)$ & $20.39(9.5)$ & $2.96(1.03)$ \\
CaPB & $3.26(0.7)$ & $19.94(7.85)$ & $2.12(0.6)$ & $16.03(7.4)$ & $2.92(0.96)$ & $2.19(0.7)$ & $18.7(6.8)$ & $3.08(1.09)$ \\
IB & $1.78(0.47)$ & $32.08(0.16)$ & & & & & &
\end{tabular}

CrPB: Cranial polar branch. CaPB: Caudal polar branch. IB: Intermediate branch. ASB: anterior segmental branch. PSB: posterior segmental branch. SD: standard deviation

\section{DISCUSSION}

Previous studies of the RA in pigs have been limited to the description of its distribution patterns into the renal parenchyma, with scarce morphometric data on this structure. (Evan et al.). The external dimensions of the kidneys of our work are consistent with those reported in prior studies (Schwarze \& Roldán, 1970; Getty, 1995; Sampaio et al., 1998); the mean dimensions reported in humans are: Length $11.1 \mathrm{~cm}$, cranial pole $6.44 \mathrm{~cm}$, caudal pole $5.49 \mathrm{~cm}$, and thickness $3.29 \mathrm{~cm}$, thus being slightly larger than those reported in pigs (Sampaio \& Lacerda, 1989; Sampaio \& Aragao, 1992).

An asymmetric origin of the RA is described in the pig, which has also been reported for human kidneys in previous studies (Odman \& Ranniger, 1968; Saldarriaga et al., 2008a,b). In our study the asymmetric origin found (49.6 $\%)$, is less than the reports in humans, which correspond to 65.6-90\%, with the right RA being more cranial (55\%), similar to what has been found in humans, that is, between 49.1-75\% of the cases (Merklin \& Michels, 1958; Saldarriaga et al., 2008a,b). The distance between the sites of origin of the RA in our series was slightly longer than what has been reported in humans by Saldarriaga et al. (2008a,b) (2.9 mm).

The presence of multiple RAs (Type III) has not been described in pigs; in humans this variation has been reported in $10-50 \%$ of cases, a much higher figure than that observed in our series $(1.7 \%)$. Similarly, as to the side of occurrence, our series found a predominance of the left side, whereas studies in humans have reported this anatomical variant with a higher frequency in the right side (Saldarriaga et al., 2008a,b; Aristotle et al.; Saritha et al.; Vatsala et al.).

The caliber of the RA in humans has been reported within a range of 4.15-5.9 mm (Behar et al., 2002; Aytac et al., 2003; Saldarriaga et al., 2008a,b), and a length of between 31.6-111 mm (Janschek et al., 2004; Dhar \& Lal, 2005; Saldarriaga et al., 2008a,b). These dimensions are similar to what we found in our work $(5.11 \mathrm{~mm}$ for caliber and $30.1 \mathrm{~mm}$ for length). The right RA was longer than the left RA, consistent with what has been described in humans. (Saldarriaga et al., 2008a,b).

Concerning the RA distribution pattern, our findings are consistent with a previous study that points to Type I as having the highest incidence, but while in this study this type was observed in $97.1 \%$ with similar presentation in both right and left RAs, Evan et al. reported it in $77.3 \%$ of the cases, with a significant predominance of the right side. Similarly, they characterized Type I pattern $(\mathrm{a} ; \mathrm{b})$ but did not report the percentage of presentation, an information that is described in our work. This study included the Ic Type, characterized by the presence of $\mathrm{CrPB}$ and $\mathrm{CaPB}$ branches and one IB that irrigates the respective segment of the kidney. This pattern, observed in $6.1 \%$ of the specimens, 
has not been reported in prior studies (Schwarze \& Roldán; Evan et al.). In humans a division of the RA in anterior and posterior branches has been described, which in turn give rise to the segmental branches that are distributed into the renal parenchyma without anastomoses, thus determining a terminal irrigation (Bass, 1954).

Of note is the significant difference in the incidence of Type II pattern between Evan et al. (22.7\%) and our findings $(1.3 \%)$. These differences can be explained by the size of the specimens, the methodologies used, and the biological characteristics of the different crossings of the pig breeds studied.

Understanding the varied morphologic expression of the RA and its branches in humans has become an imperative in order to meet physiological and surgical needs. A depurated skill based on the knowledge of the anatomy of these structures is needed for the performance of diverse procedures such as vascular sutures, kidney transplant, substance infusion assays, and catheterization. In this regard, due to its similar irrigation, the pig kidney is an excellent procedural model that allows for the development of the said techniques (Kaouk et al.; Hammond et al.; Bagetti Filho et al.).

\section{CONCLUSIONS}

The description in this work of a Type Ic distribution pattern with the presence of one IB and of the segmental e inter-lobar branches enrich the knowledge of the morphology of the renal irrigation in pigs. Similarly, the finding of multiple renal arteries in our study, which had not been previously described, shows another component of similarity between the renal irrigation in humans and pigs. The particular morphological characteristics of the RA and its branches in pigs allow for proposing this animal model for surgical and hemodynamic procedural applications.

\section{ACKNOWLEDGMENTS}

To Vijagual Refrigerating Plant in the city of Bucaramanga, Colombia, for the donation of parts for the conduction of this research, and to undergraduate students Fausto Arenas, Josimar Sneider Rincón, and Juan Camilo Álvarez for their participation in the preparation of the studied renal specimens.

GÓMEZ, F. A.; BALLESTEROS, L. E. \& ESTUPIÑAN, H. Y. Caracterización morfológica de las arterias renales en el cerdo. Análisis comparativo con el humano. Int. J. Morphol., 35(1):319-324, 2017.

RESUMEN: A pesar de su importancia como un modelo experimental, la información sobre la arteria renal en los porcinos es escasa. El objetivo de este trabajo fue determinar las características morfológicas de la arteria renal (AR) y sus ramas en cerdos. Fueron estudiados 121 pares de riñones de cerdos destinados al sacrificio con método de aturdimiento. Las AR y sus ramas fueron perfundidas con resina poliéster (Palatal $85 \%$ t Estireno $15 \%$ ) y sometidas a infusión de $\mathrm{KOH}$ (hidróxido de potasio) para corrosión total. Se midieron calibres, evaluaron trayectorias y relaciones con estructuras arteriales adyacentes. Se evaluó las variables continuas con el test de $t$ student y las variables discretas con el test de chi cuadrado de Pearson. El nivel de significancia usado fue de p $<0,05$. El origen de la AR fue simétrico en 57 muestras (50,4\%), siendo la arteria renal derecha la más craneal en el $55 \%$ de los casos. Se observó arterias renales únicas en el 98,4\%, sin diferencias significativas de lado $(\mathrm{p}=0,31)$. El calibre y la longitud de la AR fue 5,11 mm (SD 1,35) y 30,1 mm (SD 8,63) respectivamente. En el 97,1 \% se observó un patrón de expresión de la AR que origina una rama polar craneal y una caudal (Tipo I). La distribución en ramas polares craneal y caudal de la AR es superior a lo descrito en la literatura, en tanto que las características morfométricas no han sido reportadas en estudios previos. Estos hallazgos contribuyen al mejor conocimiento en el campo de la anatomía comparada del riñón y permiten postular al modelo porcino en aplicaciones procedimentales y hemodinámicas.

PALABRAS CLAVE: Arteria renal; Ramas polares; Porcino; Ramas segmentales.

\section{REFERENCES}

Aristotle, S.; Sundarapandian \& Felicia, C. Anatomical study of variations in the blood supply of kidneys. J. Clin. Diagn. Res., 7(8):1555-7, 2013. Aytac, S. K.; Yigit, H.; Sancak, T. \& Ozcan, H. Correlation between the diameter of the main renal artery and the presence of an accessory renal artery: sonographic and angiographic evaluation. J. Ultrasound Med., 22(5):433-9, 2003.

Bagetti Filho, H. J.; Pereira-Sampaio, M. A.; Favorito, L. A. \& Sampaio, F. J. Pig kidney: anatomical relationships between the renal venous arrangement and the kidney collecting system. J. Urol., 179(4):162730, 2008.
Behar, J. V.; Nelson, R. C.; Zidar, J. P.; DeLong, D. M. \& Smith, T. P. Thinsection multidetector $\mathrm{CT}$ angiography of renal artery stents. A. J. R. Am. J. Roentgenol., 178(5):1155-9, 2002.

Dhar, P. \& Lal, K. Main and accessory renal arteries--a morphological study. Ital. J. Anat. Embryol., 110(2):101-10, 2005.

Evan, A. P.; Connors, B. A.; Lingeman, J. E.; Blomgren, P. \& Willis, L. R. Branching patterns of the renal artery of the pig. Anat. Rec., 246(2):21723, 1996.

Graves, F. T. The anatomy of the intrarenal arteries and its application to segmental resection of the kidney. Br. J. Surg., 42(172):132-9, 1954. 
Hammond, L.; Ketchum, J. \& Schwartz, B. F. A new approach to urology training: a laboratory model for percutaneous nephrolithotomy. J. Urol., 172(5 Pt. 1):1950-2, 2004.

Hodson, C. J. The Pig as a Model for Studying Kidney Disease in Man. In: Tumbleson, M. E. (Ed.). Swine in Biomedical Research. Vol. 3. New York, Plenum Press, 1986. pp.1691-704.

Janschek, E. C.; Rothe, A. U.; Hölzenbein, T. J.; Langer, F.; Brugger, P. C.; Pokorny, H.; Domenig, C. M.; Rasoul-Rockenschaub, S. \& Mühlbacher, F. Anatomic basis of right renal vein extension for cadaveric kidney transplantation. Urology, 63(4):660-4, 2004.

Kaouk, J. H.; Gill, I. S.; Desai, M. M.; Banks, K. L.; Raja, S. S.; Skacel, M. \& Sung, G. T. Laparoscopic anatrophic nephrolithotomy: feasibility study in a chronic porcine model. J. Urol., 169(2):691-6, 2003.

Merklin, R. J. \& Michels, N. A. The variant renal and suprarenal blood supply with data on the inferior phrenic, ureteral and gonadal arteries: a statistical analysis based on 185 dissections and review of the literature. J. Int. Coll. Surg., 29(1 Pt. 1):41-76, 1958.

Odman, P. \& Ranniger, K. The location of the renal arteries. An angiographic and postmortem study. Am. J. Roentgenol. Radium Ther. Nucl. Med., 104(2):283-6, 1968

Shashikala, P.; Anjali, W.; Anshuman, N. \& Jayshree, D. A case report: double renal arteries. Int. J. Anat. Var., 5:22-4, 2012.

Saldarriaga, B.; Pérez, A. F. \& Ballesteros, L. E. A direct anatomical study of additional renal arteries in a Colombian mestizo population. Folia Morphol. (Warsz.), 67(2):129-34, 2008a.

Saldarriaga, B.; Pinto, S. A. \& Ballesteros, L. E. Morphological expression of the renal artery: A direct anatomical study in a Colombian half-caste population. Int. J. Morphol., 26(1):31-8, 2008b.

Sampaio, F. J. B. \& Mandarim-de-Lacerda, C. A. Morphométrie du rein. Étude appliquée à l'urologie et à l'imagerie. J. Urol. (Paris), 95:77-80, 1989.

Sampaio, F. J. \& Aragao, A. H. Inferior pole collecting system anatomy: ita probable role in extracorporeal shock wave lithotripsy. J. Urol., 147:3224, 1992.

Sampaio, F. J.; Pereira-Sampaio, M. A. \& Favorito, L. A. The pig kidney as an endourologic model: anatomic contribution. J. Endourol., 12(1):45$50,1998$.

Saritha, S.; Jyothi, N.; Praveen Kumar, M. \& Supriya, G. Cadaveric study of accessory renal arteries and its surgical correlation. Int. J. Res. Med. Sci., 1(1):19-22, 2013

Schwarze. E. \& Roldán, R. M. Compendio de Anatomía Veterinaria. Tomo 2. El Sistema Visceral. Zaragoza, Editorial Acribia, 1970. pp.230.

Getty, R. Sisson y Grossman. Anatomía de los Animales Domésticos. 5th ed. Barcelona, Masson, 1995. pp.1430-1.

Vatsala, A. R.; Ajay, K. T.; Mavishettar, G. F. \& Sangam. A study on branching pattern of renal arteries. Int. J. Anat. Res., 2(1):270-2, 2014.

Xu, L. X.; Holmes, K. R.; Moore, B.; Chen, M. M. \& Arkin, H. Microvascular architecture within the pig kidney cortex. Microvasc. Res., 47(3):293-307, 1994

\section{Corresponding author: Fabián Alejandro Gómez Torres DMV. MSc \\ Docente Asociado \\ Universidad Industrial de Santander \\ Bucaramanga \\ COLOMBIA}

E-mail: falegom@uis.edu.co

Received: 21-06-2016

Accepted: 25-10-2016 